Andes, the main line from Chile to Buenos Ayres, has been disturbed for about three miles by the eruption of hillocks.

AN Australian paper states that a live frog had been brought to the office that had been found three or four days before incased in the solid rock, in the drive of the Sultan mine, Barry's Reef, at a depth of 400 it. below the surface. The little animal looked bright-eyed and very lively, and was apparently none the worse for its long term of solitary imprisomment.

\section{SCIENCE IN AMERICA*}

THE forthcoming number of the American $70 u$ rnal of Science will contain an extremely interesting announcement in regard to American palieontology, namely, the discovery by Prof. Marsh in the Cretaceous beds of the Rocky Mountain region, of a huge pterodactyl, or flying lizard. This form has long been known as characteristic of the deposits of Europe, and has always attracted much attention from its combination of the characters of the bird and reptile; but until this announcement by Prof. Marsh the family was not supposed to be represented in the New World. The addition therefore of the pterodactyl, to the list of American genera, shows a marked increase in palreonto. logical affluence, and gives additional point to the statements made some time ago, that America, instead of being greatly inferior to the Old World in the variety of its vertebrate fossil remains, now bids fair to greatly exceed it in this respect. The name assigned to this new species is "Pterodactylus Orveni " (in honour of Prof. Richard Owen of London), and it is believed to have had an expanse between the tips of the wings of at least twenty feet.-We regret to learn that during the recent revolution on the Isthmus of Telruantepec a large number of valuable collections in natural history, made for the Smithsonian Institution by its correspondent in that region, Prof. Sumichrast, were entirely destroyed in the course of the conflicts of the opposing parties.--The annual report of the Smithsonian Institution for I869 has, after an unusual delay, just made its appearance from the public printing-office, and contains the customary variety of interesting matter, which has made this report so much sought after by persons of scientific tastes in the United States. Preceded by the secretary's usual report of the operations of the Institution for the year, it contains in an appendix numerous articles, partly orjginal, and partly translations from such foreign journals as are not readily accessible to the American student. Among these may be mentioned biographies of Thomas Young, Augustus Bravais, Von Martius, and Marianni; an important original paper by Dr. Sterry Hunt on the chemistry of the earth; and one by Marey on the phenomena of flight in the animal lingdom; an extended paper by General Simpson, tupon the march of Coronado in search of the seven cities of Cibola; one by Sir John Lubbock, on the social and religious condition of the lower races of man, \&c. The report is in no way inferior in interest to its predecessors. -Salt Lake City has lately been the scene of considerable activity, in connection with the arrival there of several government exploring parties, for the purpose of fitting out for their summer's campaign. Among these may be mentioned Mr. Clarence King, who continues his geological and topographical exploration of the fortieth parallel eastward through Colorado; Major Powell, who renews his examination of the canons of Green River and the Colorado, and who is detained at Salt Lake City in consequence of the late melting of the mountain snows, the low stage of water preventing him from passing through the canons; and a portion of Prof. Hayden's party is also at the same place collecting animals and supplies for a visit to the Yellow Stone region. - By advices from South America we learn that on the 25th of April last Chili was visited by two of the severest earthquakes that have been experienced in the country since $185 \mathrm{r}$. The first shock in Valparaiso was not preceded by any warning sound, and its suddenness and intensity created considerable alarm, the streets of the city being filled in a short time by people who rushed out from their dwellings in a state of indescribable confusion.-Many of our readers are familiar with the names of Mr. Thomas Say, of Philadelphia, and Mr. C. A. Leseur, as having been among the most prominent of our naturalists during the early part of the present century, and as having added many new species to the lists. The labours of $\mathrm{Mr}$. Say were directed largely toward the invertebrata, embracing more particularly the insects, shells, and crustaceans. Many of

* Communicated by the Scientific Editor of Harper's Weekly. his explorations were in the vicinity of Beesley's Point, New Jersey, where species were obtained by him that have ever sin remained almost unknown to science. Several examinations have been more recently made on the New Jersey coast, for the express purpose of recovering these forms; and one of the most successful was prosecuted last spring, under the direction of Prof. Verrill, of Yale College, who, with several companions, spent a week at Somers Point and Beesley's Point. The results of their labours were much greater than they had anticipated, as they not only obtained a large proportion of all the missin forms, but secured quite a number of new species, and cletected the occurrence, for the first tine, of others previously known as belonging much farther south, among them two echinoderms, of which Cape Hatteras was the limit previously ascertained Their "catch" for the week summed up about I75 species of marine animals--about 25 of fishes, 50 of crustaceans, 25 of worms, 50 of mollusks, and 15 of radiates and sponges.

\section{MR. BENTHAM'S ANNIVERSARY ADDRESS TO THE LINNEAN SOCIETY}

\section{(Continued from page I52)}

GERMANY, or rather Central Europe from the Rhine to the Carpathians and from the Baltic to the Alps, is, as to the greater part of it, a continuation of that generally uniform but gradually changing biological region which covers the Russian empire. It is not yct affected by those peculiar western races which either stop short of the Rhine and Rhone or only here and there cross these rivers with a few stragglers; the mountains, however, on its southern border show a biological type different from either of those which limit the Russian portion, indicating in many respects, as I observed in 1869 , a closer connection with the Scandinavian and high northern than with the Pyrenean to the west or the Caucasian to the east. The verifying and follow. ing up these indications gives a special interest to the study of German races, their variations and affmities. In so far as formal specific distinctions are concerned, all plants and animals, with the exception of a few of those whose minute size enables them long to escape observation, may now be considered as well known in Germany as in France and England ; and in Germany especially the investigation of anatomical and physiological characters has of Jate years contributed much to a more correct appreciation of those distinctions and of the natural relations of organic races. But much remains still for the systematic biologist, and especially the zoologist, to accomplish. Among the very numerous floras of the country, both general and local, there are several which have been worked out with due reference to the vegetation of the immediately surrounding regions, but corresponding complete faunas do not appear to exist. A few in some branches have been commenced; but in these, as in the numerous papers on more or less extended local zoology, as far as I can perceive, animals, and especially insects, seem to be considered only in respect of the forms they assume within the region treated of, frequently with a very close critical study of variations or races of the lowest grades, but neglecting all comparison with the forms a species may assume or be represented by in adjoining or distant countries.

Germany holds a first rank amongst civilised nations in respect of her biological works in most departments; they probably exceed in bulk those of any other country. Her publishir $g$ scientific academies and other associations, her zoological museums and gardens, her botanical herbaria and university gardens, her zoologists and botanists of world-wide reputation, are far too numerous to be here particularised. She excels all other nations in the patient and persevering elaboration of minute details, although she must yield to the French in respect of clearness and conciseness of methodical exposition. Her speculative tendencies are well known, aud the great impulse given to them since the spread of "Darwinismus" appears to have thrown systematic biology still further into the background; the sad events of the last twelvemonth have also temporarily suspended or greatly interfered with the peaceful course of science. Thus the zoological works contained in the lists $I$ have received are almost all dated in 1868 or 1869 , and have been already analysed in the reports of Wiegmann's "Archiv" and in the 5th and 6th volumes of the "Zoological Record," and the principal ones relating to exotic zoology will have to be referred to further on. In Systematic Botany also but little of importance has been published within the last ten years beyond the great "Fiora Brasiliensis," which, since the death of Dr. v. Martius, has been 